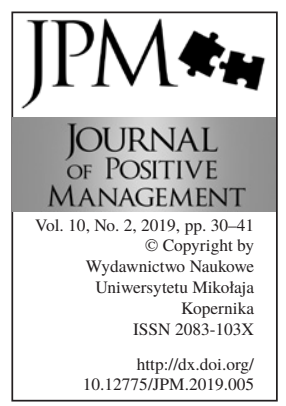

\title{
THE 5S METHOD AND ITS INFLUENCE ON EMPLOYEE WORK REQUIREMENT PRACTICES WHICH CAN HAMPER LEAN SERVICE INTRODUCTION
}

\author{
Wojciech Ulrych
}

\author{
University of Lodz, Faculty of Management, Lodz, Poland \\ e-mail: wojciech.ulrych@uni.lodz.pl
}

\begin{abstract}
Purpose: Implementing new methodology requires a new way of thinking and behaviour. The introduction of lean can bring about problems that can derive from adapting to such a change, and also from employees being used to established customs, and from a lack of knowledge regarding the change. As a consequence, employee work requirement (EWR) practices may appear which can hamper lean introduction. This paper is an attempt to show how the aforementioned EWR practices can be reduced by the most basic lean method called the 5S`s.
\end{abstract}

Methodology: Based on the author's own research a model has been developed. Modeling of structural equations required an indication of the theoretical model. A 5 point Likert scale questionnaire was developed and used.

Findings: The 5S method can indeed decrease EWR practices and its usage is of the highest importance during the initial five years of lean service introduction.

Implications/ limitations for practice: The EWR practices support each other which means that managers can spot them all in practice. This is why the most important thing is the appropriate introduction of the $5 \mathrm{~S}$ method which constitutes the future success of lean service methodology. The research sample consisted of 173 purposefully selected lean-oriented service departments.

Originality/value: The 5S - EWR model shows how well the fundamental 5S tool can manage with initial problems which derive from both a business model change and lean requirements.

Keywords: employee work requirement practices, lean service, problems in lean introduction, the $5 \mathrm{~S}$ method

Paper type: Research paper

\section{Introduction}

Lean management is a Japanese concept which is widely known in European and US companies for its fundamental principles including, amongst others, a teambased approach and a broadly-anchored empowerment approach in terms of taking more responsibility by individuals (Abdi et al., 2006; Chen and Cox, 2012; 
Martyniak, 2002). Although its general ideas of customer-added value and waste reduction are believed to be mostly shared by a broad body of management in the manufacturing industry, there are inhibitions and even doubts about how to put the lean service ideas into practice (Chen and Cox, 2012; Chiarini, 2013). From a lean service viewpoint, waste can be found in transactional processes (Chiarini, 2013). This is why before the introduction of lean principles in any service activity it is essential to begin with a deep understanding of inherent service aspects and a good knowledge of customer value (Andrés-López, 2015). The lean concept derives from team-oriented Asian culture where even the issue of equal pay is understood differently in comparison to the Western way of thinking (Liker and Hoseus, 2016). It is necessary to modify the lean methods in such a way that they meet the individual's needs and fit into the culture of the organization (Zimniewicz, 2003).

As mentioned an array of challenges can develop during lean introduction such as employee work requirement (EWR) practices which can hamper lean methodology. When properly managed the $5 \mathrm{~S}$ method can help to overcome any problems in order to go further with lean (Chiarini, 2013).

This paper's aim is to present the current literature and the author's findings regarding the influence of the $5 \mathrm{~S}$ method on current EWR practices that go against lean methodology. Such practices can be seen during the first few years of lean introduction. However, lean introduction is said to be a never-ending journey to perfection (Charron et al., 2015, p.199). These practices constitute challenges for staff and are addressed in the research process later in this paper.

\section{Employee work requirements (EWR) practices which inhibit lean methodology}

The current Polish HRM literature devotes much room to highlight the importance of job description and specifications as a comprehensive organizing tool to make decisions regarding HRM functions (Król and Ludwiczyński, 2007). The same importance goes to individual pay-for-performance through performance appraisal and assessment (Borkowska, 2004; Pocztowski, 2008). Simultaneously the question of developing individual human capital is often discussed as being part of the organizational human capital (Król and Ludwiczyński, 2007). Much attention is given to the concept of individuality in both Polish and westernoriented HRM literature. The lean business model can have an impact on the aforementioned practices.

Maurer (2016) points out that the introduction of huge changes can unsettle staff and so it's better to use a small steps approach in accordance with kaizen philosophy. Lean EWR practices derives from lean assumptions regarding a challenging employee's obligatory multi-task flexibility and a must to get used to standard work at different workstations (Danielsson, 2013; Locher, 2011) to abide 
THE 5S METHOD AND ITS INFLUENCE ON EMPLOYEE

Wojciech Ulrych by lean rules like the $5 \mathrm{~S}$ method. As a result of it there is a need to cross over borders of job descriptions to better concentrate on both tasks and information flow paths through relation between them (Locher, 2011; Spear and Bowen, 1999; Król, 2018). Rothwell et al. (2012) indicate that the traditional job description is a potential static, non-adjusting lean inhibitor.

Lean requires participation in interdisciplinary training, allows flexibility of work and participation in multifunctional teams, and this gives the opportunity to learn and perform new duties (Locher, 2011). It is taken for granted that there is a need to constant employees training, build teams, extend participation, so that employees could help each other and replace each other (Abdi et al., 2006). Teamwork requires the reconciliation of individual and team goals (DahlgaardPark and Dahlgaard, 2006). As a consequence of all these facts there is no room for individual performance appraisal or pay for individual performance (Locher, 2011; Womack, 2015). Nevertheless there are two perspectives of work organization in a lean office (Danielsson, 2013), in which the former expresses more rigid and individual-oriented management than the latter:

- consistent with Taylor's scientific management (so called neo-Tayloristic approach), which expresses the need for a individual standardized work, loyalty, limiting the role of conflict and team goals as well as no rotation of the leadership role in the team and open office system,

- and a team-based approach that helps to solve problems and learn for the need to shorten the process time. The space in the office is treated as a managerial tool. Employee and teams have more power and responsibility; individual work and its effects are just as important as team work; planning individual and team effectiveness includes the indication of goals; spontaneous and informal meetings between managers and employees are required; rotation between positions and teams is the norm; team leader rotation is also a passer-by in the team. In assessing the employee's effectiveness, a constant change in the working environment must be taken into account.

Bear in mind that business model change may bring about initial resistance to assuming different duties and cross training, and 3 months or sometimes longer people need to "settle in" to the new process (Locher, 2011). Not everyone is eager to accept a work standard (this is a part of the 5S) and some employees can initially revert back to previously worked ways (Huntzinger, 2006). Many practitioners mistakenly focus on lean tools and equipment, whilst neglecting the element of respect for people (Locher, 2011; Schonberger, 1986). As a result of this totally changed "world of work", challenges and problems can occur at the beginning of lean introduction, such as when it comes to sustaining self-discipline in the operating workflow (Imai, 2018), having too much work-in-progress at one given time, unexpected backlogs and difficulty in work experience exchange 
(Locher, 2011), dealing with overwork symptoms (Taylor, 2013), uneven workload sharing (Locher, 2011) and competition for resources.

The aforementioned EWR practices seen in lean services veer away from the well-known HRM practices and solutions which in turn highlight the importance of individuality of each person in terms of job position-oriented ownership, individual performance review, pay-for-performance and competitiveness. This is why the EWR practices derive from the following lean inhibitors (Hadis and Mansouri, 2014): employees resistance to change, functional hierarchical management structure, human errors in the implementation process, implementation of multiple improvement programs, and the lack of knowledge of the practices and their origin in manufacturing.

When difficulties come out they can be classified as waste in accordance with lean methodology. But there are also instances for long-lasting or permanent problems and challenges in this regard. Taylor's (2013) report points out that evidence of health and well-being problems in administrative and service work is just as worrying as the examples of production workers. They come from a customer service call center, where the emphasis on short talk cycles and automatic workflow are typical for these organizations. Excessive standardization and intensive work monitoring are the only lean features that lead to overloading of employees. The content of the work carried out by employees is monotonous. This situation leads to many psychological and physical health problems. The goals related to shortening time are considered by workers as the most important inconvenience of work. Proofs of a Mental Work Organization Research indicate that performance management and lean are integrated only to create a new form of intensified and more strict regulation in the field of work.

The above facts represent challenges that every individual within the team must cope with to complement the lean as well as $5 \mathrm{~S}$ spirit. No doubt a managerial help have to be in place to overcome obstacles.

\section{The $5 \mathrm{~S}$ method which can overcome EWR practices}

Locher (2011) points out that workplace organization (often called 5S) is the most widely used lean tool in office and service environments. $5 \mathrm{~S}$ is widely presented in 5 points accountability-oriented areas which stand for:

- Sort: identify unnecessary items that are found in an area.

- Set-in-Order: place items in the best locations possible.

- Shine: maintain an area in good working condition (clean and safe). It is about regular cleaning routines.

- Standardize: policies, procedures, practices to maintain the first three S's.

- Sustain: discipline to the first four S's.

However the 5S is not only the question of tidiness. Chiarini (2013) sets out that $5 \mathrm{~S}$ allows workers to concentrate only on their workplace, thus saving
THE 5S METHOD AND ITS INFLUENCE ON EMPLOYEE

Wojciech Ulrych 
THE 5S METHOD AND ITS INFLUENCE ON EMPLOYEE

Wojciech Ulrych them from criticism in case of failure. Team lean activities are aimed primarily at achieving goals and implementing quality standards for the $5 \mathrm{~S}$ method. Finally, after having installed $5 \mathrm{~S}$ at the workplace, workers and their managers start thinking according to visual management logic. After having applied 5S with success, in fact, it is usually much easier to spot work-in-progress (WIP) of activities or obstacles that were hidden by the mess. $5 \mathrm{~S}$ represents the discipline which supports kaizen philosophy. If 5S fails to be introduced properly there's no point in continuing the lean introduction, because the company isn't ready for the long way to improvement. Tapping (2005) highlights that remuneration should therefore be an influence for the use of the $5 \mathrm{~S}$ tool.

In principle, the team initiates and monitors the implementation of the $5 \mathrm{~S}$ tool, and after its implementation, a single employee - as part of the team - is responsible for maintaining the order of the given working area. Management support in this regard is necessary (Tapping, 2005). In the case of 5S, the standardization stage (number four), requires the definition of visual work standards in the form of a document and defining it in the tasks, location, name of the responsible employee, time of completion and required resources. Importantly, assigned tasks can be rotated among team members.

\section{Methodology, findings and hypothesis verification}

The paper's research aim is to develop, verify and analyze findings of a model presenting an influence of the $5 \mathrm{~S}$ method on the EWR practices that can hamper lean methodology. Research questions respond to the lean service inhibitors (Hadis and Mansouri, 2014) that can lead to the disadvantageous EWR practices:

1. Are there any employee work requirement (EWR) practices that indicate problems in the operating workflow?

2. Do these practices support each other to build a construct?

3. Can the $5 \mathrm{~S}$ method influence any EWR practices that can hamper lean introduction?

4. Does the number of years of lean influence the model? Do a value stream mapping (VSM) or Kaizen have anything to do with it?

A 5 point Likert scale questionnaire was developed and used. The results present a fragment of the author larger research concentrating on the influence of employee performance management on a lean service. For the current research purpose secondary database was used. The research sample consisted of 173 purposefully selected departments in terms of the following criteria:

- service delivery and identification of lean requirements (principles, methods, tools and lean measures) by department managers,

- the analyzed departments included support for the production process (i.e. maintenance, forwarding, logistics, $28.9 \%$ ), as well as departments 
providing services to internal and external clients (HR, accounting and finance, purchasing, quality control, customer service, R\&D and lean, $57.22 \%)$ and "other" service departments (13.87\%).

Modeling of structural equations required an indication of the theoretical model (Figure 1) and variable constructs which were developed based on the presented theory review. The development of variables for model constructs was carried out using IBM SPSS Statistics and SPSS Amos software.

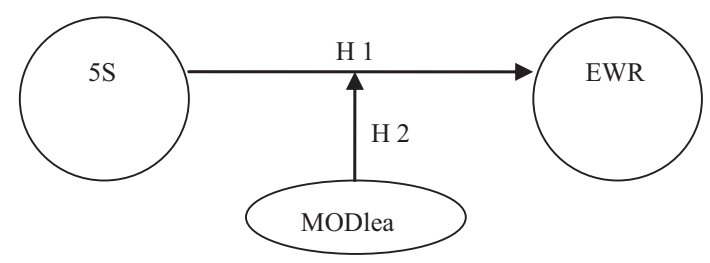

Two hypotheses derived from the theoretical model:

$\mathrm{H} 1$ : The $5 \mathrm{~S}$ method favorably influences a set of EWR practices that can hamper lean assumptions.

H 2: The "years of lean", as well as the implementation of Kaizen and VSM reduce the implementation of disadvantageous EWR practices in the model.

The content of the model's constructs are as follows:

- $5 \mathrm{~S}$ - workplace organization in terms of workstation order, cleaning and team self-discipline. The construct (Table 3) was developed based on Locher's (2011) findings.

- EWR - disadvantageous HRM practices for lean which come out during the initial stages of lean introduction (Table 1).

- MODlean - moderators; a number of years of lean in the departments divided into two groups: (1) up to 5 years and (2) >= 6 years in the departments; value stream mapping introduction VSM, or Kaizen (continuous improvement) introduction. The content of these last two moderators is presented later in Table 5 .

The first step to build the model was to develop two constructs: EWR and 5S. To build the EWR construct (Table 2) there were 9 practices based on the literature gathered, which are referenced in Table 1. However, only 5 of the 9 items were used to build the EWR construct. This means that the practices create a mutually consistent supportive set in those departments where lean methodology is practiced. It is also worth paying attention to those practices that were excluded from building this construct.
THE 5S METHOD AND ITS INFLUENCE ON EMPLOYEE

Wojciech Ulrych

Figure 1. The model of the impact of the $5 \mathrm{~S}$ method on the reduction of disadvantageous EWR practices hampering lean - based on the literature

Source: based on the author's own research. 
THE 5S METHOD AND ITS INFLUENCE ON EMPLOYEE

Wojciech Ulrych

Table 1. Employee work requirements (EWR) practices that hamper lean introduction $(\mathrm{n}=173)$

Source: based on the author's own research.

Table 2. EWR practices that hamper lean - a construct $(\mathrm{n}=173)$

Source: based on the author's own research.

\begin{tabular}{|c|c|c|}
\hline Items & Descriptions & References \\
\hline p12.6 & $\begin{array}{l}\text { Staff are not eager to work at different } \\
\text { workstations on a regular basis }\end{array}$ & $\begin{array}{l}\text { Danielsson 2013; Locher 2011; Spear, } \\
\text { Bowen 1999; Król, 2018; Rothwell et } \\
\text { al., 2012; Abdi et al., } 2006\end{array}$ \\
\hline $\mathrm{p} 12.10$ & $\begin{array}{l}\text { The way in which employees perform their } \\
\text { work is not important if only the work is } \\
\text { carried out }\end{array}$ & $\begin{array}{l}\text { Danielsson, 2013; Locher, 2011; Taylor, } \\
2013\end{array}$ \\
\hline p13.1 & $\begin{array}{l}\text { The employee serves several customers at } \\
\text { the same time or does various tasks (i.e. } \\
\text { prepares and sends) at the same time (i.e. } \\
\text { overload) }\end{array}$ & Locher, 2011; Taylor, 2013 \\
\hline p13.5 & $\begin{array}{l}\text { The exchange of experience between } \\
\text { specialists is limited }\end{array}$ & Locher, 2011 \\
\hline p13.6 & $\begin{array}{l}\text { Employees are unevenly burdened with } \\
\text { work }\end{array}$ & Locher, 2011; Taylor, 2013 \\
\hline p14.8 & $\begin{array}{l}\text { Employees deal with a too high level of } \\
\text { work in progress (WIP) }\end{array}$ & $\begin{array}{l}\text { Locher, 2011; Taylor, 2013; Chiarini, } \\
2013\end{array}$ \\
\hline
\end{tabular}

The department competes with other de-

p18.5 partments for various resources (eg finan- Locher, 2011 cial, material, time related to workload)

Employees of the department / cell have

p21.4 difficulties in implementing several impro- Locher, 2011 vement programs at the same time Employees of the department / cells are p21.6 not able to maintain new ways of working and revert back to their previous habits

Locher, 2011; Huntzinger, 2006; Imai, 2018

\begin{tabular}{lll}
$\begin{array}{l}\text { Correlation } \\
\text { of positions } \\
\text { in total }\end{array}$ & $\begin{array}{l}\text { Factor } \\
\text { loading }\end{array}$ & $\begin{array}{l}\text { Cronbach`s } \\
\text { Alfa }\end{array}$ \\
\hline
\end{tabular}

Items Descriptions

0.326

0.571

p12.10

The way in which employees perform carried out

The employee serves several customers at

p13.1 the same time or does various tasks (i.e. prepares and sends) at the same time (i.e. overload)

$0.259 \quad 0.486$

0.623

\begin{tabular}{llll}
\hline p13.5 & $\begin{array}{l}\text { The exchange of experience between spe- } \\
\text { cialists is limited }\end{array}$ & 0.284 & 0.555 \\
\hline p13.6 & $\begin{array}{l}\text { Employees are unevenly burdened with } \\
\text { work }\end{array}$ & 0.543 & 0.793 \\
\hline
\end{tabular}

p14.8 Employees deal with a too high level of work in progress (WIP)
0.749 
When taking a closer look at Table 2 we can see that the Nully condition regarding correlation of positions in total is unfulfilled because two items (p13.1 and p13.5) are far below 0.4. But when building a new construct, there is the possibility to leave these two items whilst being aware of the fact that it is the researcher's decision based on the model assumptions. Cronbach`s Alfa coefficient is lower than 0.7 which is required in the statistical literature. However, when a new construct is being built its value is acceptable.

In turn the $5 \mathrm{~S}$ construct only consists of 4 items (Table 3 ). The construct meets the statistical requirements, both in terms of factor loadings (over 0.5) as well as Cronbach's Alpha coefficient (over 0.7).

\begin{tabular}{llll}
\hline Items & Descriptions & $\begin{array}{l}\text { Factor } \\
\text { loading }\end{array}$ & $\begin{array}{l}\text { Cronbach's } \\
\text { Alfa }\end{array}$ \\
\hline \multirow{2}{*}{ p16.1 } & $\begin{array}{l}\text { Each employee regularly identifies and disposes of unneces- } \\
\text { sary items on the station (e.g. materials, books), puts the ne- } \\
\text { cessary items in marked places (e.g. in the described drawers), } \\
\text { cleans and ensures the safety of the workplace - performs } \\
\text { these activities routinely and in accordance with the standards. }\end{array}$ & \multirow{2}{*}{0.754} \\
\cline { 1 - 2 } p16.2 & $\begin{array}{l}\text { The principles of maintaining order in the workplace are pre- } \\
\text { sented in the form of visual work standards, e.g. a document } \\
\text { specifying tasks, places, names of responsible employees and } \\
\text { the time of performing particular activities. }\end{array}$ & .850 \\
\cline { 1 - 2 } p16.3 & The rules of keeping the team order require a periodic audit. & .747 \\
\cline { 1 - 2 } p16.5 & $\begin{array}{l}\text { The principles of maintaining the order of the workplace } \\
\text { require employee training. }\end{array}$ & .752 \\
\hline
\end{tabular}

An attempt was then made to build the general model of the impact of the 5S method on the reduction of disadvantageous EWR practices which hamper lean in accordance with the theoretical model (Figure 1). As a result the global model (5S-EWR) has been developed (Figure 2).

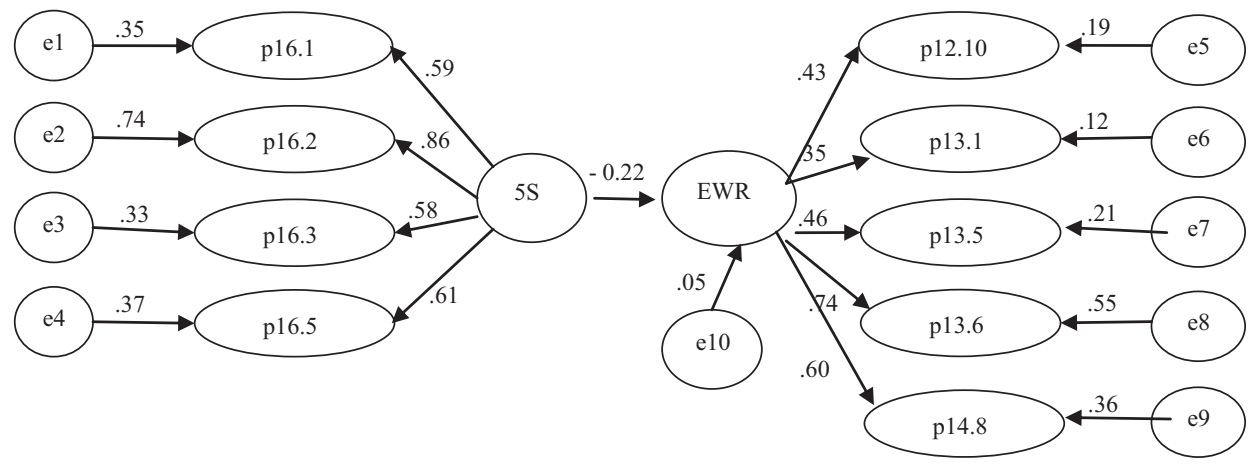

Figure 2. The model of the impact of $5 \mathrm{~S}$ on the reduction of disadvantageous EWR practices hampering lean findings

Source: based on the author's own research. 
THE 5S METHOD AND ITS INFLUENCE ON EMPLOYEE

Wojciech Ulrych

Table 4. Results of the 5S - EWR model fits

Source: based on the author's own research.
A few words are needed for the presented model. Power correlation is weak $(-0,22)$, but the test of statistical significance of the model $(p$-value $)=0.045$. The minus value -0.22 accounts for the strength with which the use of the $5 \mathrm{~S}$ method decreases EWR practices which hamper lean methodology. In Table 4 some of the goodness-of-fit measures for the model are presented. The model is not perfect, but the presented results in terms of model fits meet the requirements.

\begin{tabular}{|c|c|c|c|}
\hline The goodness-of-fit measure & Model & & Result \\
\hline $\begin{array}{l}\text { Chi-square }\left(\lambda^{2}\right) \\
\text { df } \\
p\end{array}$ & \multicolumn{2}{|c|}{$\begin{array}{l}\text { Chi-square }=66,270 \\
\text { Degrees of freedom }=26 \\
\text { Probability level }=, 000\end{array}$} & requirement was not achieved \\
\hline \multirow{2}{*}{$\begin{array}{l}\text { RMSEA, i.e. root mean squ- } \\
\text { are error approximation }\end{array}$} & RMSEA LO 90 & HI 90 & \multirow{2}{*}{$\begin{array}{l}\text { requirement was achieved (slight } \\
\text { adjustment) }\end{array}$} \\
\hline & .067 & .104 & \\
\hline Chi-square $\left(\lambda^{2}\right)$ divided by $\mathrm{df}$ & 2.55 & & requirement was achieved \\
\hline GFI of Joerskog & 0.94 & & requirement was achieved \\
\hline AGFI of Joerskog & 0.9 & & requirement was achieved \\
\hline
\end{tabular}

The next step was to introduce a moderator to the 5S-EWR model. The model was moderated using three items which are presented in Table 5. For two of them (VSM and Kaizen) the parameters of the model in terms of p-value are not statistically significant probably due to the sample size - there are very few departments that did not introduce them into practice. This is why it was impossible to divide the sample into two groups of those that introduced them into practice and those who did not.

However, the number of years that lean has been used makes a huge difference on the model. When lean methodology has been in place for up to 5 years $(n=113$, $65,3 \%$ ) the influence between the 5S method and EWR practices (Figure 3 ) is even stronger (- 0.34) in comparison to the general model presented in Figure 2. Power correlation in the model changes but the model itself does not change, thus its model fits stays unchanged. The test of statistical significance of the model p-value $=0.015$. However, when lean has been in the departments for 6 or more years $(n=60,34,7 \%)$ the test of statistical significance of the model p-value $=0.591$, meaning that there is no influence in terms of statistical significance.

The above results can be explained. During the first 5 years of lean in the departments, the $5 \mathrm{~S}$ method is often the only best-introduced lean solution whereas other lean requirements, methods, measures are either not introduced or work poorly. The most important thing is the appropriate introduction of the $5 \mathrm{~S}$ method. The importance of the $5 \mathrm{~S}$ method among other lean solutions to decrease EWR practices that can inhibit lean can be then easily observed. As time passes 
other lean tools can be put into place. They take over the role of the $5 \mathrm{~S}$ method which influences EWR practices. Additionally, all employees get experienced over time and the business processes begin to flow more smoothly. This doesn't mean that the $5 \mathrm{~S}$ method disappears or is neglected. It is still a base to support lean methodology in general.

\begin{tabular}{ll}
\hline Items & Descriptions \\
\hline years of lean & up to 5 and $>=6$ years \\
\hline Kaizen & $\begin{array}{l}\text { The team meets regularly and works on implementing improvements in a given } \\
\text { area of the organization's activity }\end{array}$ \\
\hline \multirow{2}{*}{ VSM } & $\begin{array}{l}\text { The processing of information, documents or the provision of a service is sub- } \\
\text { ordinated to the expectations of the final recipient and takes the form of a value } \\
\text { stream map for the customer }\end{array}$ \\
\hline
\end{tabular}

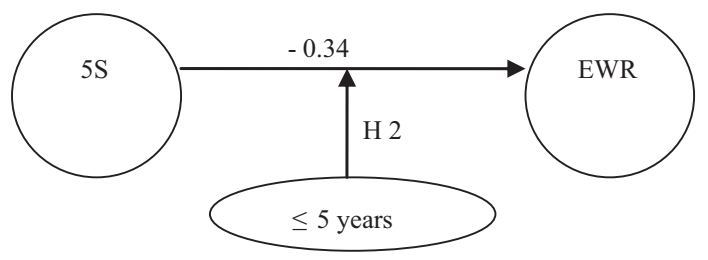

Having all the presented results in mind it is now possible to verify the hypotheses. The $5 \mathrm{~S}$ method favorably influences a set of EWR practices that hamper lean assumptions. This is why $\mathrm{H} 1$ is confirmed. In general, it is a must to have it if a company plans to develop lean methodology. Its influence is especially important during the first years of lean because it is the first and most important tool to reduce workstation problems. However, neither VSM nor Kaizen were moderators in the model and this fact is a bit surprising. This is why $\mathrm{H} 2$ is partly confirmed.

\section{Conclusion}

The aforementioned verification of hypotheses brings some remarks regarding the findings. Firstly, the sample of service departments tested is small and so it is not possible to speak of representativeness in statistical terms. Secondly, the researched departments are still changing towards lean requirements, which demand the adaptation of Japanese, team-oriented solutions to individual Polish requirements. Thirdly, the line managers, not the workers, observed the EWR practices and then were respondents of the research.
THE 5S METHOD AND ITS INFLUENCE ON EMPLOYEE

Wojciech Ulrych

Table 5. The content of moderator

(MODlean)

Source: based on the author's own research.

Figure 3. The model of the impact of $5 \mathrm{~S}$ on the reduction of disadvantageous EWR practices hampering lean with moderator "years of lean" - findings

Source: based on the author's own research. 
THE 5S METHOD AND ITS INFLUENCE ON EMPLOYEE

Wojciech Ulrych
When answering research questions posed in this study it should be noted that: (1) there are EWR practices observed by managers that hamper the operating workflow. Although there are some practices found in the literature that can constrain lean introduction, few of them were spotted by department managers. (2) EWR practices correlate to each other to form a construct. They support each other meaning that managers can spot them all in practice. (3) The $5 \mathrm{~S}$ method supports the EWR construct and decreases the lean EWR inhibitors. This is the clue of the findings. The $5 \mathrm{~S}$ method constitutes the future success of lean methodology. (4) The number of years of lean functioning in the departments influence the model. The usage of the $5 \mathrm{~S}$ method is always important to reduce problems regarding lean inhibitors but the first years in practice is of the highest importance.

Lean methodology introduction pays attention to contextual factors that influence the change. As it was highlighted in this paper it can be observed that EWR practices appear in a natural way to go against the new idea. The $5 \mathrm{~S}$ method certainly seems to be the inherent solution to reduce practices that inhibit lean service introduction.

\section{References}

Abdi, F., Shavarini, S., Hoseini, S. (2006), "Glean Lean: How to Use Lean Approach in Services Industries?", Journal of Services Research, Vol. 6 Special Issue, pp. 191-206. Andrés-López, E., González-Requena, I., Sanz-Lobera, A. (2015), "Lean Service: Reassessment of Lean Manufacturing for Service Activities", Procedia Engineering, No. 132, pp. 23-30. DOI: 10.1016/j.proeng.2015.12.463

Borkowska, S. (2004), Strategie wynagrodzeń, Oficyna Ekonomiczna, Kraków.

Charron, R., Harrington, H.J., Voehl, F., Wiggin, H. (2015), The Lean Management Systems Handbook, Taylor \& Francis Inc., Portland, United States.

Chen, J.C., Cox, R.A. (2012), "Value Stream Management for Lean Office - A Case Study", American Journal of Industrial and Business Management, Vol. 2 No. 2, pp. 17-29. DOI: 10.4236/ajibm.2012.22004

Chiarini, A. (2013), Lean Organization: from the Tools of the Toyota Production System to Lean Office, Springer Milan Heidelberg New York Dordrecht London, SpringerVerlag Italia.

Dahlgaard-Park, S.M., Dahlgaard, J.J. (2006), "In Search of Excellence - Past, Present and Future", in: Kreativ und Konsequent, pp. 57-84, available at: http://lup.lub.lu.se/ record/931524 (accessed 8 July 2019).

Danielsson, Ch.B. (2013), "An explorative review of the Lean office concept", Journal of Corporate Real Estate, Vol. 15 No. 3/4, pp. 167-180.

Hadid, W., Mansouri, S.A. (2014), "The lean-performance relationship in services: a theoretical model", International Journal of Operations \& Production Management, Vol. 34 No. 6, pp. 750-785.

Huntzinger, J. (2006), Why Standard Work is not Standard: Training Within Industry Provides an Answer, AME Association for Manufacturing Excellence, Fourth Issue. 
Imai, M. (2018), Gemba kaizen. Zdroworozsqudkowe podejście do strategii ciagłego rozwoju, MT Biznes, Warszawa.

Król, T. (2018), Lean management po polsku. O dobrych i złych praktykach, Wydawnictwo Helion, Gliwice.

Król, H., Ludwiczyński, A. (Eds.) (2007), Zarządzanie zasobami ludzkim. Tworzenie kapitału ludzkiego organizacji, Wydawnictwo Naukowe PWN, Warszawa.

Liker, K.J., Hoseus, M. (2016), Kultura Toyoty. Serce I dusza filozofii Toyoty, MT Biznes sp. z o.o., Warszawa.

Locher, D. (2011), Lean Office and Service Simplified, CRC Press, Taylor and Francis Group, Boca Raton.

Martyniak, Z. (2002), Nowe metody i koncepcje zarzadzania, Wydawnictwo Akademii Ekonomicznej w Krakowie, Kraków.

Maurer, R. (2016), Filozofia kaizen. Małymi krokami ku doskonałości, Wydawnictwo HELION, Gliwice.

Pocztowski, A. (2008), Zarządzanie zasobami ludzkimi. Strategie, procesy, metody, Polskie Wydawnictwo Ekonomiczne, Warszawa.

Rothwell, W.J., Graber, J., McCormick, N. (2012), Lean but Agile: Rethink Workforce Planning and Gain a True Competitive Edge, Amacom, American Management Association.

Schonberger, R.J. (1986), World Class Manufacturing: The Lessons of Simplicity Applied, The Free Press, New York.

Spear, S., Bowen, H.K. (1999), "Decoding the DNA of the Toyota Production System", Harvard Business Review, Vol. 77 No. 5, pp. 96-106.

Taylor, Ph. (2013), "Performance Management and the New Workplace Tyranny. A Report for the Scottish Trades Union Congress, Executive Summary", available at: https:// strathprints.strath.ac.uk/57598/1/Taylor_2013_performance_management_and_the_ new_workplace_tyranny.pdf (accessed 1 December 2019).

Tapping, D. (2005), The lean office pocket guide. Tools for the elimination of waste in the administrative areas, MCS Media Inc.

Womack, J.P. (2015), "Why are rewards tied to individual performance so dangerous?", available at: https://planet-lean.com/womack-rewards-metrics-yokoten/ (accessed 7 July 2019).

Zimniewicz, K. (2003), Współczesne koncepcje i metody zarządzania, Polskie Wydawnictwo Ekonomiczne, Warszawa.
THE 5S METHOD AND ITS INFLUENCE ON EMPLOYEE

Wojciech Ulrych 